Keywords:

Wildfire

Fire entrapments

Sardinia

Fatalities

Histórico:

Recebido 15/I |/2016

Aceito 10/04/2017

Palavras chave:

Incêndio Florestal

Encurralamento pelo fogo,

Sardenha

Fatalidades

${ }^{+}$Correspondência: adriancardil@gmail.com

DOI:

\section{FATALITIES IN WILDLAND FIRES FROM I 945 TO 2015 IN SARDINIA (ITALY)}

ABSTRACT: The worst outcome of wildland fires is the loss of human lives, a recurrent phenomenon over the last few decades in Sardinia, Europe and worldwide. This work analyzes all recorded fatalities in wildland fires in Sardinia from 1945 to 2015 and trends in terms of annual number of fatalities. This time period was split due to legal and socioeconomic changes periods (1945-1975; 1976-2000; 200I-20I5). We classified accident types during wildland fires to study the most frequent causes of fatalities and how they were related I) to involved human groups (professional firefighters, auxiliary firefighters, and civilians, 2) to fire size and 3) to extreme weather conditions. We observed that the annual number of victims was higher in the $198 \mathrm{I}-1999$ period than in other periods with 2.6 fatalities per year. Entrapment is the most frequent cause of death within the fire professional firefighters $(75.6 \%)$. The rate of fatalities seemed to be higher in the 198I1999 period for "civilians" and lower for "professional firefighters". We detected that the annual number of "civilian" fatalities is higher in the $198 \mathrm{I}-1999$ period with I.6 fatalities per year. The calculated rate for "army forces \& volunteer firefighters" group was in the middle ground. Entrapment is the most frequent cause of death with a percentage of $75.6 \%$. Fire size is a key factor in the fatality occurrence because over $80 \%$ of deaths in wildland fires (without considering aerial accidents) happened in fires larger than 100 ha. Days with extreme weather conditions (high temperature or strong winds) were also instrumental because at least $47 \%$ of entrapments occurred in this kind of days.

\section{FATALIDADES EM INCÊNDIOS FLORESTAIS DE I945 A 2015 NA SARDENHA (ITÁLIA)}

RESUMO: O pior resultado dos incêndios florestais é a perda de vidas humanas, um fenômeno recorrente ao longo das últimas décadas na Sardenha, Europa e em todo o mundo. Este trabalho analisa os registros de fatalidades em incêndios florestais na Sardenha, de 1945 até 2015 e tendências em termos de número anual de mortes. Este período de tempo foi dividido devido a alterações legais e sócioeconômicas (1945-1975; 1976-2000; 200I-20I5). Nos classificados os tipos de acidente durante os incêndios florestais para estudar as causas mais frequentes de mortes e como elas se relacionados com I) os grupos humanos (bombeiros profissionais, bombeiros auxiliares e civis), 2) ao tamanho do fogo e 3) condições meteorológicas extremas. Observamos que o número anual de vítimas foi maior no período de 198I-1999 do que em outros períodos, com 2,6 mortes por ano. Encurralamento pelo fogo é a causa mais frequente de morte de "bombeiros profissionais" (75,6\%). A taxa de mortes parecia ser mais elevada no período I98I-I999 para "civis" e menor para "bombeiros profissionais". Detectamos que o número anual de mortes de "civis" foi maior no período de 198I-1999, com I,6 mortes por ano. A taxa calculada para o grupo "forças do exército e os bombeiros voluntários" foi no meio termo. Tamanho do fogo é um fator fundamental para a ocorrência de fatalidade, porque mais de $80 \%$ das mortes em incêndios florestais (sem considerar os acidentes aéreos) aconteceram em incêndios maiores que 100 ha. Dias com condições meteorológicas extremas (alta temperatura ou ventos fortes) também foram fundamentais, porque pelo menos $47 \%$ dos encurralamentos pelo fogo ocorreram nestes tipos de dias.

' University of Lleida - Lérida, Spain

${ }^{2}$ Corpo Forestale e di Vigilanza Ambientale - Italy 


\section{INTRODUCTION}

Wildland fires are a growing threat worldwide, mainly in fire-prone areas (CARDIL et al., 20I4; SALIS et al., 2012; PEREIRA et al., 20I I). Europe has experienced a large number of wildfires that have caused enormous losses in terms of human lives, environmental damage and economic disruptions. The average annual burnt area in the European Union from 2000 to now is approximately 500,000 ha, causing estimated annual losses of 2 billion $€$ (JRC- European Commission, 20I3). The loss of human lives is the worst outcome of wildland fires and populated areas have a higher exposure to large wildland fires (LWF) than ever (VIEGAS, 2009). Wildland urban interface areas have increased in Sardinia, Italy and many other countries in last years. Both rural and coastal areas have been populated by homes which have contributed to the increase of wildland urban interface areas. Additionally, climate change and rural land abandonment are influencing fire occurrence and extreme fire behavior. Climate change is providing extreme weather conditions in terms of drought and temperature (CARDIL et al., 20I3; FLANNIGAN et al., 2000) and rural land abandonment provides high fuel loads and fuel complex continuities across the landscape, increasing the probability of developing large wildland fires (VEGA-GARCÍA AND CHUVIECO, 2006).

The number of fatal victims in forest fires was over 500 individuals from 1980 to 2007 (VIEGAS et al., 2009) and wildland fires are one of the main threats for forests degradation (FAO, 20I3). Many catastrophic wildland fires with losses happened in Sardinia including 13 fatalities in Portisco fire (1989) and 9 fatalities in Curraggia wildfire (1983). Portisco fire involved I 3 civilian people in an entrapment when escaping from their houses by car during a mistral wind-driven wildfire of 700 ha and maquis vegetation. The second one (Curraggia wildfire; $40,000 \mathrm{ha}$ ) involved 9 people during a heat wave that lasted 10 days. The incident occurred in a steep slope near the village of Tempio (North Sardinia) with a high amount of dry herbaceous fuels. Fatalities were recorded in other regions of the world such as Spain (Horta de San Joan, Tarragona, 2009, 5 fatalities; Riba de Saelices, GUADALAJARA, 2005, I I fatalities, CARDIL and MOLINA, 20I5), Greece (78 people died in the summer of 2007), Portugal (22 victims in 2007, Viegas, 2009), United States of America (I 33 firefighters died on 94 separate events in the 1990-1998 period (MANGAN, 2007), Mexico (19 volunteer firefighters lost their lives in Puebla in 1998 in a single fire event, Rodríguez-Trejo et al., 2000). The last large fatality in the USA involved the Granite Mountain Hotshots; 19 crew members lost their lives on June 30, 2013, on the Yarnell Hill Fire in Arizona), Australia or
Chile (CARDIL AND MOLINA, 20I5; MANGAN, 2007; VIEGAS, 2009; CABBIDU et al., 20II; HALTENHOFF, 2003). Lastly, these two are the most impressive historic accounts on fire events with fatalities: I) In Southwestern France, near Bordeaux, a forest fire kills 230 people and burns more than 100,000ha (19-August 1949) (DEVILLE, 2009), and 2) In USA (Idaho-Montana), The Great Fires of 1910 (also commonly referred to as the Big Blowup) killed 87 people and burned about I,200,000ha (EGAN, 20 I I).

Most fire managers consulted (MOLINA et al., 2010) agreed that a fire with victims escalate to a completely different emergency level. First, a new emergency (i.e., taken care of the victim) occurs during the propagation of the wildland fire, involving lots of resources to address the victim. Second, when there is a dead one in a wildland fire, social pressure increases quickly and fire suppression resources are less efficient in these situations (i.e., thinking about affected teammates (victims), suffering uncertainty). High quality training on safety protocols such as LACES or Dead Man Zone (GLEASON, 199I) should be critical to pursue a lower accident rate (MOLINA et al., 20I0). The LACES protocol includes Lookout, Anchor lines, Communications, Escape routes, and Safety zones. Elsewhere are specific details on LACES safety protocol (MOLINA et al., 20I0) or LCES protocol (USDA Forest Service, 2004).

Both firefighters and citizens are at risk in wildland fires and many people were involved in several wildland fire accidents in Sardinia. Large amounts of resources have been invested in fire suppression resources to reduce the negative consequences of fires and to provide safety to the population. However, firefighters sometimes do work in a high-risk environment and fatalities may occur. Individuals involved in different tasks of fire management are subject to diverse dangers including burnover, vehicle and aircraft accident, and medical emergencies (MANGAN, 2007). The aim of this work is to analyze all recorded wildland fires in Sardinia with fatalities from 1945 to 2015 and to try to address the following questions: (I) What are the most frequent causes of death of firefighters in wildland fires in Sardinia?; (2) Is the number of fatalities per year diminishing lately with the new implemented safety protocols and guide?; (3) Is extreme temperature favoring the probability of fatalities?; (4) Is final fire size a factor that favors the probability of victim occurrence?".

\section{MATERIAL AND METHODS}

\section{Study area}

Sardinia, Italy, is a large island in the Mediterranean Sea $\left(24,235 \mathrm{~km}^{2}\right)$ located between $38^{\circ} 5 \mathrm{I}^{\prime} \mathrm{N}$ and $4 \mathrm{I}^{\circ} \mathrm{I} 5^{\prime} \mathrm{N}$ 
latitude and $8^{\circ} 8^{\prime} \mathrm{E}$ and $9^{\circ} 50^{\prime} \mathrm{E}$ longitude (Figure I) and has a population of about I.7 million inhabitants. Overall, the island has a complex topography with hills and low mountains (RICOTTA et al. 20I2). The average elevation of the island is $338 \mathrm{~m}$ a.s.l. and the highest point is Punta la Marmora with $1834 \mathrm{~m}$ a.s.l. in the center of the island. The climate is classified as Mediterranean, with dry hot summers and an important water deficit from May to September (CHESSA AND DELITALA, 1997). The mean annual temperature ranges from $17.8^{\circ} \mathrm{C}$ in the Southern coast to $12.8{ }^{\circ} \mathrm{C}$ in the mountainous areas. Maximum temperature peaks are higher than $30.8{ }^{\circ} \mathrm{C}$ during the summer season. Average annual rainfall is $1300 \mathrm{~mm}$ in the mountains, but slightly less than $500 \mathrm{~mm}$ in the coast, and most of the annual rainfall occurs in fall and winter. The flora includes 2407 taxonomic species, with 10\% of endemic species (DE ANGELIS et al., 20I2). Large areas of the island are covered by scrub and/or herbaceous vegetation associations, comprised primarily of Pistacia lentiscus L., Arbutus unedo L., Erica arborea L., Myrtus communis L., Olea europea L., Phyllirea spp., Juniperus spp. and Cistus spp. (SALIS et al., 20I2). Woodlands and forest area is approximately $55 \%$ of Sardinia (National Forest Inventory, C.F.S., 2005) with the main tree species being Quercus ilex L., Q. suber L., Q. pubescens Willd., and Q. congesta Presl. Pine plantations with Pinus pinea L., P. halepensis Mill.,other pines and Eucalyptus sp. only spread over $3 \%$ of the island and are mainly concentrated along the coast (SALIS et al., 20I2). Pastures and agricultural lands represent about $36 \%$ while the urban areas cover $3 \%$ of the island.

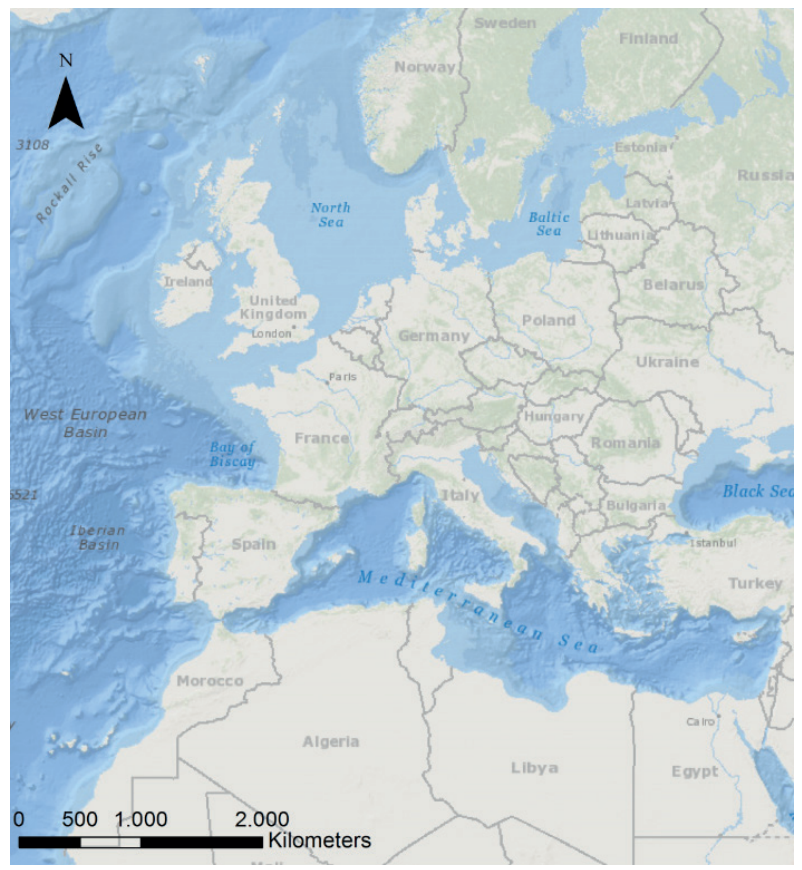

FIGURE I Geographiclocation ofSardinia(Italy) in the Mediterranean.

\section{Fire and fatalities data}

Historical fire data records with fatalities from the Sardinian Regional Forest Agency (CFVA -Corpo Forestale e di Vigilanza Ambientale) were used from 1945 to 2015 in Sardinia. The CFVA database has an entry for each wildfire ignition and provides information on date, municipality and location of the ignition, and area burned. Although information about fire size was not available before 1971 for all fires, fire size for those fires with fatalities was accessible. All fatalities recorded in the databases were verified through interviews with senior managers and by analyzing documents of the accidents and news in newspapers. Therefore, data about fatalities in wildland fires in fire suppression systems is accurate.

On average, from I97I to 2015 (from fire data base collected burned areas systematically), Sardinia experienced 2,931 fires per year and about 18,800 ha burned per year. Wildfires are typically concentrated from June to September, with the maximum of both ignitions and area burned in July (SALIS et al., 20I2). Similar to elsewhere in Euro-Mediterranean ecosystems, a few large wildland fires account for most of the burned area (CARDIL and MOLINA, 20I3). However, the aim of this work is to analyze if fire size could be an influencing factor in the victim occurrence. For this purpose, we assessed the relation between fatalities and fire size, segregating all wildland fires with victims in five size classes (Table I). We assessed if the fire size was associated with the number of victims and if the largest fires might have the highest percentage of victims.

In the case of fatalities, we evaluated the death cause in all wildland fires using fire official CVFA data as well as the available information in several newspapers. We classified all victims according to the following death causes:

a) Physical cause: this category includes different medical causes (including heart attack and dizziness);

b) Entrapment: either when a wildland fire reaches the victim or death by hot gases;

TABLE I Number of fatalities in entrapments in wildland fires and fire size classes in Sardinia (1945-20I5).

\begin{tabular}{ccc}
\hline $\begin{array}{c}\text { Wildland fire class } \\
\text { (ha) }\end{array}$ & Number of fatalities & $\begin{array}{c}\text { Percentage of fatalities } \\
(\%)\end{array}$ \\
\hline$<100$ & 7 & 12.5 \\
$>100$ & 46 & 82.1 \\
{$[100-500]$} & 1 & 1.8 \\
{$[500-1000]$} & 24 & 42.9 \\
$>1000$ & 21 & 37.5 \\
Unknown & 3 & 5.4 \\
Total & 56 & 100 \\
\hline
\end{tabular}


c) Aerial accident: either landing, or taking off, or in cruising flight;

d) Terrestrial accident: including a person stepping on a power line, accidents while driving vehicles, falling down with lethal injures;

Sardinia developed an original fire-fighting command system that had different phases since 1945. Originally, fires were extinguished by volunteers groups (slightly trained) and coordinated by the Italian National Forest Corps. In 1975 a new framework law (L. 47/75) assigned the wildfire coordination responsibility to Italian National Forest Corps. In 1985 the new CFVA (Sardinian Regional Forest and Environmental Corps) was structured (from personnel from the Italian National Forestry Corps) and renewed its components with a great recruitment in the "90s". CFVA took care of fire suppression tasks using forestry workers and rural police. In the '70's the use of helicopters and terrestrial machinery in suppression increased and the military aerial fleet appeared as a new tool. In 2000, a new Italian national law (L. 353/00) defined wildland fires as emergencies of civil protection although fire suppression efforts were still the responsibility of the CFVA. In 20I5, many personnel were involved in fire suppression in 377 municipalities: some I,400 within CFVA, approximately 2,000 forest workers and firefighers (now in FORESTAS Agency), 3,500 volunteer firefighters (from different Civil Protection), 4,000 rangers from private rangeland states ("barraccellos"), and some 700 Structural firefighters (Italian National Firemen Agency). All fatalities in Sardinia from 1945 to 2015 are shown in Table 2.

All fatalities were analyzed and classified in relation to the cause of death and the job duties of the victims in the fire suppression system. The categories used to describe the involvement of the victim in the wildland fire were the following (Table 2):

I. Professional firefighters (PF). In this category, we included forest rangers, fuel and forest managers or supervisors, fire crew members and people who worked in the fire suppression system from the Italian National Firemen Agency, CFVA and FORESTAS agency (including forestry seasonal workers);

2. Auxiliary firefighters (AF). Armed forces and volunteer firefighter groups;

3. Civilians: Many of the victims here fall in the sub-category of shepherds.

We have worked to assign a normalized presence of these groups in suppressing active fires to improve the study. We strongly recognize that amount of hours-worker (or days of work) that is committed to suppress active fires is higher for the group "professional firefighters" than for "army forces \& volunteer firefighters". Our best educated guess is that it is 4.0 times higher for "professional firefighters". This is to say that, in average, there are four "professional firefighters" for each "army \& volunteer" worker at any given fire event. This will be important latter to calculate a normalized fatality ratio.

\section{Statistical analysis}

We determined if there were significant changes in the number of dead people in Sardinia from 1945 to 2015 using three different time intervals considering socioeconomic (Law 47/1975 that assigned in the whole Italy the wildfire coordination to State Forest agency and law $353 / 2000$ that defined a wildland fire as an emergency of civil protection), land abandonment and fire suppression changes. We used three time intervals [1945-1980], [1981-1999] and [2000-2015]. The rationale behind this partition is I) from 198I more human resources are committed to fires suppression, and 2) from 2000, it is fully applied the legislation piece entitled "occupational safety consolidated text" and wildfires became a civil protection issue, not a forest problem as in previous time. In the first time interval, fuel loads and continuity were very low due the intensive agroforestry use of the territory and fires were smaller in number and mean

TABLE 2 Number of fatalities according to the cause of death and role for victims in Sardinia (1945-20I5).

\begin{tabular}{|c|c|c|c|c|c|}
\hline Role/Cause & Physical cause & Entrapment & Terrestrial accident & Aerial accident & Total \\
\hline $\begin{array}{c}\text { Professional Firefighters } \\
\text { (PF) }\end{array}$ & 1 & 12 & 4 & 0 & 17 \\
\hline Italian National Firemen Agency & 0 & 0 & I & 0 & I \\
\hline $\begin{array}{c}\text { CFVA } \\
\text { FORESTAS AGENCY }\end{array}$ & $\begin{array}{l}1 \\
0\end{array}$ & 2 & $\begin{array}{l}0 \\
3\end{array}$ & $\begin{array}{l}0 \\
0\end{array}$ & $\begin{array}{c}3 \\
13\end{array}$ \\
\hline $\begin{array}{c}\text { Auxiliary firefighters } \\
\text { (AF) }\end{array}$ & 0 & 2 & 2 & 8 & 12 \\
\hline Armed forces & 0 & 0 & 0 & 8 & 8 \\
\hline Civil Protection Volunteers & 0 & 2 & 2 & 0 & 4 \\
\hline Civilians & I & 42 & I & I & 45 \\
\hline $\begin{array}{c}\text { Civilians } \\
\text { (other civilians) }\end{array}$ & 0 & 29 & 0 & I & 30 \\
\hline Shepherds and Farmers & I & 13 & I & 0 & 15 \\
\hline Grand Total & 2 & 56 & 7 & 9 & 74 \\
\hline
\end{tabular}


size than in the second period (DELOGU et al., 20/3). In the second period, land abandonment started to be widespread and both the fuel load and fire occurrence increased. In the third period, fire agencies improved remarkably their training, fire behavior knowledge and suppression resources. Land abandonment was even more evident (in the third period) and large wildland fire occurrence with extreme behavior larger than ever. In the third period, the culture of working hard to avoid job hazard is widely spread in the firefighing operations (DELOGU et al., 20।3).

All fatalities in entrapments, terrestrial accidents or physical causes were classified in relation to either high temperature days (HTD) or to strong wind patterns with gust from 80 to $100 \mathrm{~km} \cdot \mathrm{h}^{-1}$ (no available information about wind speed in all fires) in order to identify relationships between victims and extreme fire weather (wind and temperature). HTDs provide extreme weather conditions and influence fire occurrence, fire size and behavior (CARDIL et al., 20I3; CARDIL, et al., 20I4). Additionally, HTDs could be a key factor affecting fatalities because they provide extreme conditions for firefighters (less effectiveness, tiredness, exhaustion, dehydration) and, additionally, fire behavior is more extreme (CARDIL et al., 20I3) and can entrap firefighters and vehicles. NCEP/NCAR reanalysis data from the National Center for Environmental Prediction and the National Center for Atmospheric Research (KALNAY et al., 1996) were used to characterize HTDs on a synoptic scale. NCEP outputs are available from 1948 to the present. Daily air temperature data at the $850 \mathrm{hPa}$ pressure level at midnight 00:00 UTC were analyzed to assess the influence of high lower troposphere temperatures. A high temperature day was defined as a day with an air temperature at $850 \mathrm{hPa}$ higher or equal than the $95^{\text {th }}$ percentile of that temperature in Sardinia (CARDIL et al., 20I4).

\section{RESULTS}

In the period I945-20I5, 74 people died in wildland fires in Sardinia (Table 2), of which 17 worked for the professional firefighters (PF). 12 auxiliary firefighters (AF) died in the study period. Therefore, the rest, 45 people without relation to the fire suppression systems (civilians, many shepherds) died in wildland fires. All fatalities occurred in the fire season (May to September, both included). Most of fatalities were in August (49.3\%) and July (31.5\%).

The normalized fatality rate (deaths per 100,000 burned ha) was 4.8 from 197I to 2015 (Table 3; burned area in Figure 2). We did not use the whole period [1945-
2015] due to lack of fire data in the first decades [19451970]. In the period [198|-2000], this rate was higher than in the third period [200I-20I5] (5.8 versus 3.9). These rates decreased until 4.3 in the second period and 2.3 in the third period when only considering fatalities in fire entrapments. The global fatality rate from 1971 to 2015 (when burned areas are available in all fires) considering aerial accidents was 0.78 .

TABLE 3 Ratio of fatalities in three study periods in Sardinia (1945-2015)

\begin{tabular}{cccc}
\hline Time periods & $\begin{array}{c}\text { Number of } \\
\text { years }\end{array}$ & $\begin{array}{c}\text { Number of } \\
\text { fatalities }\end{array}$ & $\begin{array}{c}\text { Annual number of fatalities } \\
\text { and standard deviation }\end{array}$ \\
\hline $1945-1980$ & 36 & 12 & $0.33 \pm 1.2$ Ia \\
$1981-1999$ & 20 & 52 & $2.60 \pm 4.44 \mathrm{~b}$ \\
$2000-2015$ & 15 & 10 & $0.60 \pm 0.82 \mathrm{ab}$ \\
Total & 71 & 74 & $1.02 \pm 2.68$ \\
\hline
\end{tabular}

Mean values in a column in each time period followed by the same letter are not significantly different $(p<0.05)$

\section{Trends}

The mean annual number of fatalities in wildfires in Sardinia from 1945 was 1.02 (Figure 3). Significant differences were found among the three studied periods in relation to the annual number of fatalities. In the first period [1945-1980] 12 people died in wildland fires (0.33 fatalities per year). In the period [198I-2000], the annual number of fatalities was significantly higher than in the first period ( $p$-value $=0.0055$; Figure 3 ) with 52 deads (2.6 fatalities per year). In this second period, we have the worst two recorded cases in terms of human losses in Sardinia: Portisco's fire (1989) with 13 fatalities (entrapment while escaping in a car convoy with smoke when people run away) and Curraggia's fire (1983) with 9 fatalities in an entrapment. In the last period [200I-20I5], the number of fatalities was 10 ( 0.6 fatalities per year).

\section{Groups}

Fatality rates were the higher for "civilians" and the lower for PF. Differences among AF and PF fatality rates were not significant at $\mathrm{p}$-value $<0.05$ (Table 4). During the 1981-1999 period (when most fatalities occur), if we consider that fire exposure in PFs is much more than for AF, PF normalized losses are lower than AF normalized losses ( $p$-value $=0.02$; Table 4).

\section{Causes}

In relation to the total number of fatalities in Sardinia, fire entrapment was the most frequent cause with 56 victims ( $75.7 \%$ of the total number of deaths). Aerial accidents comprised I $2.2 \%$ (9 victims), terrestrial 


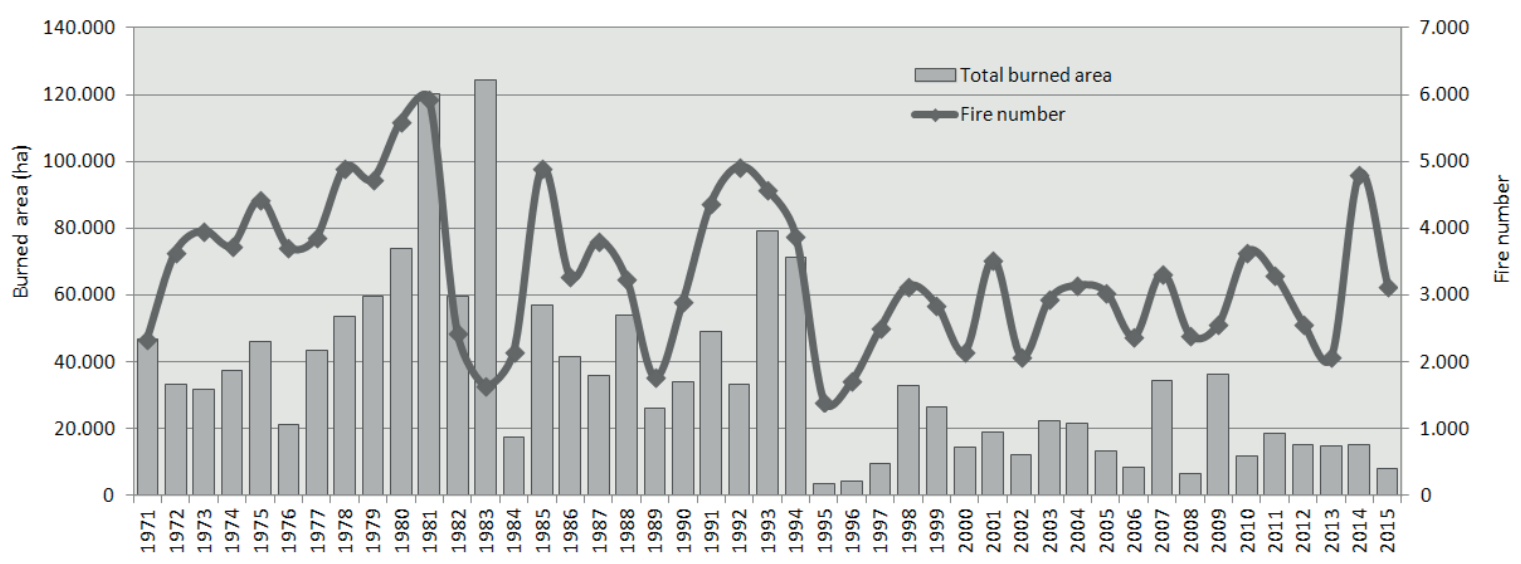

FIGURE 2 Total burned area and fire number in Sardinia from 197| to 20I5

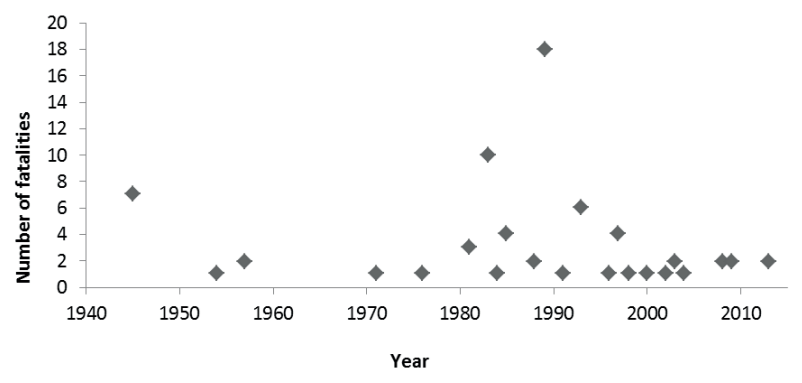

FIGURE 3 Annual number of fatalities in wildfires in Sardinia (1945-20I5).

accidents $9.5 \%$ (7 victims) and physical causes $2.7 \%$ (2 victims; Table 2). Table 2 shows the number of fatalities in relation to the cause of death and role of the victims in Sardinia from 1945 to 2015.

\section{Fire size}

Significant differences in the leading cause of mortality across different fire sizes were found. For fires larger than 100 ha, $82.1 \%$ of deaths fall in the fire entrapments cause. For fires over 500 ha, this percentage was $80.4 \%$ and for fires over I,000 ha, 37.5\% (Table I). Considering terrestrial accidents, aerial accidents and fatalities due to physical causes, all victims occurred in fires smaller than 100 ha (none in fires larger than 100 ha).

\section{Extreme weather conditions}

We studied both high temperature days (HTDs) and strong wind days (SWDs thereafter) with gust from 80 to $100 \mathrm{~km} \cdot \mathrm{h}^{-1}$ to check their share of total fatalities in these class days. In fire entrapments fatalities, 26 firefighters ( $46.4 \%$ of the total) died under HTDs. $28 \%$ of total deaths in terrestrial accidents occurred under HTD. However, the percentage of deaths in aerial accidents under HTD was 0.

Regarding extreme wind events recorded, we worked with data from 16,790 days in the register in Olbia Costa Smeralda weather station (40 53' 56.49" $\mathrm{N}$, 9० 30'56.33" E). These days are from 1969 to 2015. Only 7 days (out of 16,790) had maximum wind speed $80 \mathrm{~km} /$ he and higher. This is $0.004 \mathrm{I} \%$ of the days. Under SWDs, I 8 people died in Portisco fire ( 13 deaths) and Porto S. Paolo fire (5 deaths). This happened near touristic settlements, generally trying to escape in narrow roads, into a car or waking, in days of strong mistral (NW) wind speed $80-123 \mathrm{~km} \cdot \mathrm{h}^{-1}$. This is $24.3 \%$ of total deaths in SWDs.

\section{Discussion}

Even though the new safety measures, protocols and investments in fire suppression such as Dead Man Zone or LACES (GLEASON, 1991; MOLINA et al., 2010) are fully implemented in Sardinia since 2008, the number of fatalities in wildland fires did not decrease in the study period in Sardinia. The annual number of victims increased significantly in the second period [ 1981-1999] (2.6 fatalities per year) from to the first period [ 1945-1980] (0.33 fatalities per year). In the third period [2000-20I5], the number of victims decreased significantly. However, when referring only to Professional Firefighters (PF), the normalized number of fatalities in wildland fires did not decrease significantly from the 1981-1999 (second) period to the 2000-20I5 (third) period. This is a paradox because new safety measures, protocols and investments in fire suppression such as Dead Man Zone or LACES (GLEASON, 1991; MOLINA et al., 2010) were implemented during the third period; more specifically from 2000 to 2008. This means that there are fully implemented in Sardinia since 2008 and partially since 2000. However; we have 6 fatalities 
TABLE 4 Number and normalized number of fatalities considering the exposure factor for professional firefighters, Armed forces and volunteer firefighters and civilians in three study periods in Sardinia (1945-20I5)

\begin{tabular}{|c|c|c|c|c|c|}
\hline Personnel group & Period & $\begin{array}{c}\text { Number of } \\
\text { fatalities }\end{array}$ & $\begin{array}{c}\text { Annual number of fatalities and } \\
\text { standard deviation }\end{array}$ & $\begin{array}{c}\text { Normalized number of } \\
\text { fatalities }\end{array}$ & $\begin{array}{l}\text { Annual normalized number of } \\
\text { fatalities and standard deviation }\end{array}$ \\
\hline \multirow{3}{*}{$\begin{array}{l}\text { Professional Firefighters } \\
\text { (PF) }\end{array}$} & 1945-1980 & 8 & $0.22 \pm 1.17$ & 2 & $0.055 \pm 0.29$ \\
\hline & |98|-1999 & 6 & $0.30 \pm 0.80$ & 1.5 & $0.075 \pm 0.20$ \\
\hline & $2000-2015$ & 3 & $0.20 \pm 0.56$ & 0.75 & $0.05 \pm 0.14$ \\
\hline \multirow{3}{*}{$\begin{array}{l}\text { Auxiliary firefighters } \\
\text { (AF) }\end{array}$} & 1945-1980 & 0 & 0 & 0 & 0 \\
\hline & |98|-1999 & II & $0.60 \pm 1.14$ & I I & $0.60 \pm 1.14$ \\
\hline & $2000-2015$ & I & 0.06 & I & 0.06 \\
\hline \multirow{3}{*}{ Civilians } & 1945-1980 & 4 & $0.11 \pm 0.39$ & - & - \\
\hline & $1981-1999$ & 34 & $1.70 \pm 4.26$ & - & - \\
\hline & $2000-2015$ & 7 & $0.40 \pm 0.73$ & - & - \\
\hline
\end{tabular}

from 2000 to 2007 and 5 fatalities in the period 2008-to 20I5. Similar values for a similar number of years. This fact (the number of fatalities in wildland fires did not decrease) was also found in Spain (CARDIL and MOLINA, 20I5). The increase in the number of fatalities could be related to more extreme fire behavior in last decades (CARDIL et al., 2014) and more numerous human resources in fire suppression. The more people involved in fire suppression, the more likely to have fatalities.

Fire suppression is a high-risk profession (MANGAN, 2007; VIEGAS, 2009). Society and all involved agencies have to be informed about the job hazard situations and all available protocols to try to reduce victims in wildland fires. We recommend: I) establishing new approaches to reduce the number of victims (i.e., do not involve too many people, do not involve many volunteers and do involve mostly professional firefighters), 2) increasing fire suppression safety of both personnel and civil population, 3) training with fire in prescribed burns to gain experience for both professional and volunteer firefighters (simulating stress in decision making and suffering communication difficulties to simulate an eventual large fire scenario). The larger the prescribed burn sizes the better to feel closer to potential wildland fire situations. As reported in Molina et al. (2010) in several regions of Spain and abroad, prescribed burning is seen as the key training tool to enhance firefighters safety. The reason is that specially in large prescribed fires, we are forcing the crews to relay in efficient communications as not all firefighters are able to see the whole area burning at that time. And in all prescribed burning actions we do enforce the safety protocols. This could ensure that fire crews do follow safety protocols and efficient communication protocols in an eventual fire suppression action.
These training actions (with prescribed burning) could be useful for citizens to understand a fire situation, how suppression agencies work and how they should behave in an eventual wildland fire emergencies. It is remarkable to note that most entrapments are close to roads. Today, not all roads in Sardinia are safe enough to locate fire engines to attack a wildland fire. Eastaugh and Molina (2012) have shown how to assess which roads are safer using extensive simulations with FlamMap (FINNEY, 2002). With that Eastaugh and Molina (20I2) criteria some roads could be classify as unsafe for most firefighters in suppression action.

The normalized dead accident rate (deaths per 100,000 burned ha) was 4.8 in Sardinia, a value similar to Spain with 4.5 fatalities per 100,000 burned ha. By contrast, in the United States, this value was 0.91 (MANGAN, 2007, 2009). It is true that in the US large burning areas are dealt with minimum intervention (not so many firefighters as in Europe).

The fire entrapment is the most frequent cause of death in wildland fires accounting for more than $75 \%$ of fatalities. This percentage was lower in Spain, around 50 $\%$ (CARDIL and MOLINA, 20I5) and United States, I4 $\%$ (MANGAN, 2007). Additionally, the normalized dead accident rate in entrapments in Sardinia was 4.3, a value higher than other countries like Spain (2.I5, CARDIL and MOLINA, 20I5) and United States (0.19;MANGAN (2007, 2009)). This may indicate that our LACES and Dead Man Zone protocols are not working good enough. Therefore, we could improve our figures trying to reduce the entrapments by working harder in safety protocols during fire suppression.

Considering the normalized dead rate in aerial accidents, we have got similar results in Sardinia than in Spain ( 0.78 vs 0.82 , respectively). This value was lower 
in the United States (0.22). This could be related to the higher use of aerial resources in Spain and Sardinia versus the USA. Both Spanish and Italian fire suppression systems use aerial resources even in small fires; therefore, increasing the probability of aerial accidents. Indeed, most aerial fatalities occurred in fires smaller than I00ha ( $100 \%$ in Sardinia and $56.5 \%$ in Spain). Aerial accidents require an aeronautical review of the accident causes, and this is not in the database, and therefore, we cannot go further in this review regarding cause.

Fire size is a key factor in victim occurrence in fire entrapments in Sardinia. This fact was also found in Spain (CARDIL and MOLINA, 20I5). This could be related to two factors. First, in large wildland fires, fire behavior is normally more adverse and the probability of entrapment could be higher. Second, when a fatality (or serious injury) occurs in a wildland fire, an additional emergency starts. Therefore, many resources become diverted to try to mitigate the consequences of the accident, allowing the fire to propagate more freely and thus increasing the fire size. Implementing suitable forest management could moderate the potential fire behavior and diminish the fire potential, eventually decreasing the burned areas and the probability of accidents (CARDIL and MOLINA, 20I3). It would be interesting to investigate the relationship among fatalities and vegetation types (i.e., grassland, shrub-land and forest) although we did not have enough data to perform the analysis.

Extreme weather conditions (HTD and SWD) could also influence the victim occurrence due to a high percentage of fatalities in entrapments under this type of condition that represent a mean of 6 days per year. This is similar to what was reported in Spain with a $60 \%$ of the fatalities in entrapments in wildland fires occurred under high temperature (CARDIL and MOLINA, 20I5). In this HTD conditions, fire behavior is more adverse to firefighters, although as Beaver (2002) states that it (an extreme fire behavior) is not necessary the cause accident but the lack of matching human behavior to fire behavior. Misperception of fire risk by firefighters matters. However, this high clumpy distribution is not clear in aerial and terrestrial accidents (only $14 \%$ under HTDs). Therefore, we have to focus the safety protocols to avoid entrapments under high temperature days (HTDs). Additionally, the annual average number of HTDs increased in South Europe and Sardinia from 1980 to 2010 (CARDIL et al., 20I4). Climate change projections (IPCC, 20I4) indicate that we will experience more extreme temperatures that could influence new accidents in years to come. Extreme weather conditions influence fire behavior and, therefore, increase the probability of entrapment. In addition, these conditions could affect firefighters and people due to dehydration, stress and worse working conditions. Many accidents were related to strong NW winds (Mistral winds) with a gust wind speed close to $100 \mathrm{~km} \cdot \mathrm{h}^{-1}$. These are the most important situations to lead to fatalities: extreme temperature conditions from dry air masses from Africa and strong NW wind.

\section{CONCLUSIONS}

We have more deaths (fatalities/year) since 1981 than in the 1945-1980 period. After 1981, the number of fatalities has been reduced up to 0.6 fatalities per year in 2000-20I5 period but this change was not significant. The entrapment is the most frequent death cause (75.6\%) and it is here where agencies have room for doing things better. Fire size is a key factor in fatality occurrence because over $80 \%$ of deaths in wildland fires (without considering aerial accidents) happened in fires larger than 100 ha.

Extreme weather conditions (high temperature or strong winds) influenced victim occurrence because almost half of entrapments occurred under extreme temperature days that only represent approximately a $5 \%$ of the total days in the fire season (June-September). Under extreme fire behavior, fire-fighters should act in very a different way and the accidents should not be more likely. Unfortunately, we have more accidents and this is because there is a misperception of fire risk by firefighters more often under extreme fire behavior circumstances.

High quality safety protocols and extensive training (i.e., prescribed burning operations with emphasis on safety protocols are critical to pursue a lower accident rate. Lessons learned, and shared among different agencies (national and internationally) should encourage agencies to opt for high quality training on safety protocols. Fatality rates are higher for "civilians" and lower for PF. In the 1981-1999 period (when most fatalities are present), PF normalized losses are lower than AF normalized losses. Therefore, it is important to train PF thoroughly to maintain the recent (2000-20I5) low fatality rates in these workers that are exposed to high structural job hazard in suppression actions.

\section{REFERENCES}

BEAVER, A. K. Learning to be at risk: are we victims of our own success? In: Viegas DX (ed). Proceedings of IV International Conference on Forest Fire Research. Wildland Fire Safety Summit. Coimbra, Portugal, 2002 
CABBIDU, S.; BRIGAGLIA, S.; CONGIU, F; DELOGU, G.; LARA, G.; MUNTONI, G.; USAI, L. The Curragia wildfire, analysis of an entrapment. In: SPANO, D.; BACCIU, V.; SALIS, M.; SIRCA, C. Modeling fire behaviour and risk. 201 I.

CARDIL, A.; MOLINA, D. M. Factors Causing Victims of Wildland Fires in Spain (1980-2010). Human and Ecological Risk Assessment: An International Journal 2I(I), p.67-80 2015

CARDIL, A.; EASTAUGH, C. S.; MOLINA, D. M. Extreme temperature conditions and wildland fires in Spain. Theoretical and applied climatology, v. I22, p. 219-228, 2014.

CARDIL, A.; MOLINA, D. M.; KOBZIAR, L. N. Extreme temperature days and potential impacts in Southern Europe. Natural Hazards and Earth System Sciences, v. I4, p. 3005-3014, 2014.

CARDIL, A.; MOLINA, D. M. Large wildland fires in three diverse regions in Spain from 1978 to 2010. Forest Systems, v. 22, n. 3, p. 526-534, 2013

CHESSA, P.A.; DELITALA, A. Il clima dellaSardegna. In: MILELLA, A. Collana Note Tecniche di Agrometeorologia per la Sardegna. Sassari, Italy, 1997, 17-38 p.

DE ANGELIS, A.; RICOTTA, C.; BAJOCCO, S. Phenologicalvariability drives the distribution ofwildfires in Sardinia. Landscape Ecology, v. 27, p. I535-I545, 2012

DELOGU, G. M. "Dalla parte del fuoco. Ovvero il paradosso di Bambi”. Edizioni II Maestrale, Nuoro, 20I3, 206 p.

DEVILLE, J. L'incendie meurtrier dans la forêt des Landes en août 1949. Les Éditions des Pompiers de France, Paris, 2009.

EASTAUGH, C. S.; MOLINA, D. M. Forest road and fuelbreak siting with respect to reference fire intensities. Forest Systems, v. 2I, p. I53-I6I, 2012.

EGAN, T. The Big Burn: Teddy Roosevelt and the Fire That Saved America. Houghton Mifflin Harcourt Publishing Company, 20II.

FAO. State of Mediterranean Forests 20I3. FAO, Rome, Italy, 20I3, I 74 p. [online] URL: http://www.fao.org/docrep/0 I7/ i3226e/i3226e.pdf

FINNEY, M. A. Fire growth using minimum travel time methods. Canadian Journal of Forest Research, v. 32, p. I420-I424, 2002.

FLANNIGAN, M. D.; STOCKS, B. J.; WOTTON, B. M. Climate change and forest fires. Science of the Total Environment, v. 262, p. 22I-229, 2000.

GLEASON, P. LCES - a key to safety in the wildland fire environment. Fire Management Notes, v. 54, p. 9, 1991.

HALTENHOFF, H. La Seguridad en Incendios Forestales en Chile. In: XX Jornadas Manejo del Fuego. Consejo Técnico de Coordinación. Villarrica, Chile, 2003.
IPCC. IPCC Fifth Assessment Report: Climate Change 2014: Synthesis Report. 2014.

KALNAY, E.; KANAMITSU, M.; KISTLER, R.; COLLINS, W.; DEAVEN, D.; GANDIN, L.; IREDELL, M.; SAHA, S.; WHITE, G.; WOOLLEN, J.; ZHU, Y.; CHELLIAH, M.; EBISUZAKI, W.; HIGGINS, W.; JANOWIAK, J.; MO, K. J.; ROPELEWSKI, C.; WANG, J.; LEETMAA, A.; REYNOLDS, R.; JENNE, R.; JOSEPH, D. The NCEP/NCAR 40-year reanalysisproject, Bull. Am. Meteor. Soc., v. 77, p. 437-47I, 1996.

MANGAN, R. Wildland firefighter fatalities in the United States. 1990 to 2006. Boise, National Wildfire Coordinating Group, Safety and Health Working Team, National Interagency Fire Center, 2007.

MOLINA, D. M.; CASTELLNOU, M.; GARCIA-MARCO, D.; SALGUEIRO, A. Improving fire management success through fire behaviour specialists. Research Report European Forest Institute (EFI), p. I05-I 19, 2010.

PEREIRA, M. G.; MALAMUD, B. D.; TRIGO, R. M.; ALVES, P. J. The history and characteristics of the 1980-2005 Portuguese rural fire database. Natural Hazards and Earth System Science, v. I I, p. 3343-3358, 20 I I.

RICOTTA, C.; GUGLIETTA, D.; MIGLIOZZI, A. No evidence of increased fire risk due to agricultural land abandonment in Sardinia (Italy). Natural Hazards and Earth System Science, v. 12, p. 1333-1336, 2012.

RODRÍGUEZ-TREJO, D. A.; RODRÍGUEZ-AGUILAR, M.; FERNÁNDEZ SÁNCHEZ, F.; PYNE, S. J. Educación e Incendios Forestales. Mundi Prensa, México, D. F., 2000, $201 \mathrm{p}$.

SALIS, M.; AGER, A. A.; ARCA, B.; FINNEY, M.A.; BACCIU, V.; DUCE, P.; SPANO, D. Assessing exposure of human and ecological values to wildfire in Sardinia, Italy. International Journal of Wildland fire, v. 22, p. 549-565, 2012.

USDA Forest Service. Safety Protocol Review. Southern California Geographic Area. Fire Siege of 2003. USDA Forest Service, Pacific Southwest Region, 2004, 34 p.

VEGA-GARCÍA, C.; CHUVIECO, E. Applying local measures of spatial heterogeneity to Landsat-TM images for predicting wildfire occurrence in Mediterranean landscapes, Landscape Ecology, v. 21, p. 595-605, 2006.

VIEGAS, D. X. Recent forest fire related accidents in Europe. JRC Scientific and Technical Reports.European commission, 2009. 
